\title{
APLIKASI MESIN BERKAS ELEKTRON (MBE) SEBAGAI ALTERNATIF FIKSATOR PADA PEWARNAAN BATIK WARNA ALAM
}

\author{
Application of Electron Beam Machining (EBM) as Alternative Fixator for Batik with \\ Natural Dyes
}

\author{
Lilin Indrayani ${ }^{1}$, Wiwien Andriyati ${ }^{2}$, Elin Nuraini ${ }^{2}$ dan Mutiara Triwiswara ${ }^{1}$ \\ ${ }^{1}$ Balai Besar Kerajinan dan Batik, Jl. Kusumanegara 7 Yogyakarta \\ ${ }^{2}$ Pusat Sains dan Teknologi Akselerator Badan Tenaga Nuklir Nasional, Tambak Bayan, Caturtunggal, \\ Depok, Sleman
}

\author{
Korenspondesi Penulis \\ Email : indrayanililin@gmail.com
}

$\begin{array}{ll}\text { Naskah Masuk } & : 15 \text { Mei } 2020 \\ \text { Revisi } & : 12 \text { Juni } 2020 \\ \text { Disetujui } & : 19 \text { Juni } 2020\end{array}$

Kata kunci: batik, curing, zat warna alam, berkas elektron, ramah lingkungan

Keywords: batik, curing, natural dye, electron beam, eco friendly

\section{ABSTRAK}

Batik merupakan salah satu warisan budaya Indonesia yang harus dilestarikan. Hal ini mempengaruhi peningkatan industri batik di Indonesia dengan berbagai ragam motif dan ciri khas daerah. Namun seiring dengan berkembangnya industri batik maka semakin marak pula isu beban pencemaran lingkungan akibat limbah yang ditimbulkan oleh zat warna sintetis dari proses pewarnaan batik. Dalam upaya mewujudkan batik ramah lingkungan maka potensi sumberdaya alam Indonesia dapat dikembangkan melalui pemanfaatan zat warna alam sebagai pengganti zat warna sintetis. Namun penggunaan logam berat sebagai bahan fiksator pada zat warna alam menjadi persoalan yang harus diselesaikan agar tidak menambah beban pencemaran lingkungan. Penelitian ini bertujuan untuk mengetahui pengaruh radiasi berkas elektron sebagai upaya untuk mensubstitusi proses fiksasi menggunakan logam pada proses batik warna alam. Metode yang digunakan adalah aplikasi energi radiasi berkas elektron pada kain batik tanpa proses fiksasi dan dengan proses fiksasi menggunakan tiga jenis bahan fiksator yaitu kapur $\left(\mathrm{CaCO}_{3}\right)$, tawas $\left(\mathrm{K}_{2} \mathrm{SO}_{4} \cdot \mathrm{Al}_{2}\left(\mathrm{SO}_{4}\right)_{3} \cdot 24 \mathrm{H}_{2} \mathrm{O}\right)$ dan tunjung $\left(\mathrm{FeSO}_{4}\right)$. Adapun zat warna alam yang digunakan adalah secang (Caesalpinia sappan), mahoni (Swietenia mahagoni). tegeran (Cudrania javanensis) dan tingi (Ceriops tagal). Hasil penelitian menunjukkan bahwa radiasi berkas elektron dapat mempengaruhi hasil proses pewarnaan batik yang lebih ramah lingkungan dengan kualitas yang baik sesuai ketentuan SNI Batik dan dapat mengurangi konsentrasi logam berat dalam limbah batik dalam rangka mewujudkan industri batik yang berkelanjutan.

\section{ABSTRACT}

Batik is one of Indonesia's cultural heritages that must be preserved. This affects the improvement of the batik industry in Indonesia with a variety of motives and regional characteristics. But along with the development of the batik industry, the issue of environmental pollution burden is also rife due to the waste generated by synthetic dyes from the batik coloring process. In an effort to create environmentally friendly batik, Indonesia's natural resource potential can be developed for the use of natural dyes instead of synthetic dyes. However, the use of metals as fixators in natural dyes is a problem that must be resolved so as not to increase the burden of environmental pollution. This study 
aims to determine the effect of electron beam radiation as an attempt to substitute the fixation process with metals as fixator materials on batik using natural dyes coloring. The method used was the application of eletron beam radiation energy on batik cloth without the fixation process and with the fixation process with the application of three types of fixator material namely lime $\left(\mathrm{CaCO}_{3}\right)$, alum $\left(\mathrm{K}_{2} \mathrm{SO}_{4} \cdot \mathrm{Al}_{2}\left(\mathrm{SO}_{4}\right)_{3} .24 \mathrm{H}_{2} \mathrm{O}\right)$, tunjung $\left(\mathrm{FeSO}_{4}\right)$. The natural dyes used were secang (Caesalpinia sappan), tingi (Ceriops tagal), tegeran (Cudrania javanensis) and mahogany (Swietenia mahagoni). The final result of this research was that the electron beam radiation could affect the production of environmentally friendly batik with good quality in accordance with SNI Batik and could reduce the concentration of heavy metals in batik waste to achieve a sustainable batik industry.

\section{PENDAHULUAN}

Batik merupakan salah satu karya seni tradisional Indonesia yang telah menjadi budaya nasional sekaligus memberikan kontribusi bagi perekonomian negara. Batik diminati di berbagai negara karena nilai kreativitas, tradisi serta artistik yang dimilikinya (Meutia, 2013). Di samping itu batik juga ditetapkan oleh UNESCO (United Nations Educational, Scientific, and Cultural Organization) sebagai Warisan Budaya Tak Benda pada bulan September 2009 (Ho, 2018). Penetapan tersebut menyebabkan pertumbuhan industri batik menyebar ke berbagai wilayah di Indonesia tidak hanya di Pulau Jawa yang merupakan daerah asal budaya membatik, akan tetapi sampai daerah di luar Pulau Jawa. Di samping dampak positifnya terhadap perkembangan ekonomi, industri batik juga menimbulkan dampak negatif akibat pencemaran lingkungan yang ditimbulkan dari proses produksi batik (Mukimin, Vistanty, Zen, Purwanto, \& Wicaksono, 2018).

Proses pewarnaan batik dapat dilakukan dengan menggunakan zat warna alam (ZWA) dan zat warna sintetis (ZWS) (Amalia \& Akhtamimi, 2016). ZWS merupakan zat warna yang sebagian besar berasal dari zat-zat berbasis petrokimia (A. K. Samanta \& Konar, 2011), sedangkan ZWA berasal dari bahan alam seperti tumbuhan, hewan/serangga dan mineral (Patel, 2011). Saat ini pewarnaan batik menggunakan ZWA mulai dikembangkan sebagai pengganti ZWS seiring dengan meningkatnya kesadaran konsumen terhadap penggunaan produk-produk yang ramah lingkungan dan berkelanjutan ( $P$. Samanta, 2020).

Di Indonesia, yang merupakan negara dengan keanekaragaman hayati terbesar di dunia, tren penggunaan bahan alam sebagai sumber ZWA batik juga berdampak luas pada perekonomian Indonesia akibat adanya peningkatan nilai ekonomi dari sumber daya alam yang digunakan menjadi sumber ZWA tersebut (Mahreni, 2016).

Kelemahan dari penggunaan ZWA yaitu ketahanan luntur warna dan intensitas (ketuaan) warna yang relatif kurang baik (Amalia \& Akhtamimi, 2016). Untuk memperoleh batik dengan ketahanan luntur warna yang baik, maka perlu dilakukan proses fiksasi zat warna. Fiksasi dapat berfungsi memperkuat warna dan merubah arah warna sesuai dengan jenis logam yang terkandung di dalam fiksator serta untuk mengunci zat warna yang telah masuk ke dalam serat (Pujilestari, 2014). Dengan proses fiksasi diharapkan warna tidak akan atau sukar keluar setelah masuk ke dalam serat (Ardhianti I.D., 2011). Proses fiksasi pada prinsipnya adalah mengkondisikan zat 
pewarna yang telah terserap dalam waktu tertentu agar terjadi reaksi antara bahan yang diwarnai, dengan zat warna dan bahan yang digunakan untuk fiksasi. Bahan yang biasa digunakan untuk fiksasi adalah tawas $\left[\mathrm{K}_{2} \mathrm{SO}_{4} \cdot \mathrm{Al}_{2}\left(\mathrm{SO}_{4}\right)_{3} \cdot 24 \mathrm{H}_{2} \mathrm{O}\right]$, kapur $\left(\mathrm{CaCO}_{3}\right)$ dan tunjung $\left(\mathrm{FeSO}_{4}\right)$ (Pujilestari, 2014).

Proses fiksasi yang menggunakan bahan kimia dengan kandungan garam logam dapat menimbulkan permasalahan kesehatan dan lingkungan (Mitra, 2015). Oleh karena itu perlu dilakukan penelitian mengenai alternatif proses finishing batik dengan ZWA yang dapat meningkatkan ketahanan luntur tanpa menimbulkan dampak negatif pada lingkungan.

Pemanfaatan radiasi untuk proses finishing merupakan teknologi yang sedang berkembang di bidang tekstil. Proses finishing tekstil dengan radiasi dianggap ramah lingkungan karena dapat menggantikan panas sehingga hemat energi, tidak menggunakan bahan kimia serta tidak memerlukan pelarut sehingga hemat air. Iradiasi pada tekstil dapat dilakukan dengan menggunakan ultraviolet (UV), gamma, light-emitting diode, maupun berkas elektron (Shabbir, 2019).

Proses iradiasi pada tekstil dapat meningkatkan kualitas warna baik pada pewarnaan sintetis maupun alam (Ahmad, Adeel, \& Abbas, 2011). Pada penelitian pewarnaan tekstil menggunakan ZWA henna (Iqbal \& Adeel, 2008) dan bubuk kunyit (Adeel, Bhatti, Kausar, \& Osman, 2012) terdapat peningkatan kekuatan warna yang signifikan pada proses yang menggunakan radiasi UV dibandingkan dengan tanpa radiasi. Tekstil yang telah mengalami modifikasi menggunakan berkas elektron juga menunjukkan peningkatan kualitas pewarnaan menggunakan pewarna bejana (Hakeim, Abdou, El-Gammal, \& ElNaggar, 2012) dan kation (Shahidi, Wiener, \& Ghoranneviss, 2013). Berkas elektron juga digunakan dalam proses pewarnaan serat dengan kekuatan ultra tinggi yang sulit diwarnai (KR101485686B1, 2013). Sejauh ini belum ditemui studi mengenai penggunaan radiasi berkas elektron dalam pewarnaan tekstil menggunakan ZWA.

Pada penelitian ini berkas elektron diaplikasikan pada batik warna alam dengan dua proses. Pada proses yang pertama dilakukan aplikasi pewarnaan dengan ZWA pada kain batik tanpa dilakukan proses fiksasi. Batik tersebut selanjutnya akan diiradiasi menggunakan berkas elektron yang berfungsi untuk pengikat warna atau pengunci warna sebagai pengganti proses fiksasi. Pada proses kedua batik yang telah diwarnai dengan ZWA difiksasi terlebih dahulu kemudian diiradiasi menggunakan berkas elektron sehingga terjadi proses curing. Curing adalah proses di mana reaksi kimia (seperti polimerisasi) atau aksi fisik (seperti penguapan) terjadi dengan inisiasi suatu bentuk energi, menghasilkan perubahan fase cair ke fasa padat dengan ikatan yang rekat (Licari \& Swanson, 2011). Electron beam curing adalah suatu proses menggunakan radiasi berkas elektron untuk menginduksi reaksi kimia radiasi yaitu polimerisasi monomer dan oligomerpolimer ikatan silang dan perubahan fasa dari fase cair ke fasa padat (Danu \& Darsono, 2010). Radiasi berkas elektron baik cara pertama maupun cara kedua dapat dihasilkan dari mesin berkas elektron (MBE). MBE dapat digunakan tidak hanya untuk proses electron beam curing, tetapi dapat juga digunakan untuk proses cross- 
linking, dan degradation dari suatu produk industri (Darsono, Sukidi, \& Purwanto, 2010).

Penelitian ini bertujuan untuk mengetahui pengaruh radiasi berkas elektron menggunakan MBE terhadap ketahanan luntur warna batik dengan pewarnaan alam. Adapun ZWA yang digunakan adalah secang (Caesalpinia sappan), mahoni (Swietenia mahagoni), tegeran (Cudrania javanensis) dan tingi (Ceriops tagal). Dari penelitian ini diharapkan dapat diketahui potensi penggunaan radiasi berkas elektron dalam mengurangi keberadaan limbah logam berat pada proses fiksasi dan menghasilkan batik yang ramah lingkungan dan memiliki kualitas baik sesuai SNI batik berdasarkan parameter ketahanan luntur warnanya. .

\section{METODOLOGI PENELITIAN}

\section{Bahan Penelitian}

Bahan ZWA yang digunakan dalam penelitian ini terdiri dari empat macam tanaman yaitu secang, mahoni, tegeran dan tingi. Untuk secang dan tegeran yang digunakan adalah bagian batang kayu, sedangkan mahoni dan tingi yang digunakan adalah kulit kayunya. Proses pembatikan dilakukan menggunakan lilin batik dengan media kain katun. Fiksator yang digunakan yaitu kapur, tawas dan tunjung. Bahan-bahan tersebut diperoleh dari toko alat dan bahan batik.

\section{Peralatan Penelitian}

Peralatan yang digunakan dalam pembatikan meliputi seperangkat alat pembatikan cap, bak tempat pewarnaan, neraca, termometer, panci, saringan, pengaduk, dan kompor gas.

Sedangkan pada proses iradiasi berkas elektron peralatan yang digunakan yaitu alat preparasi sampel, Mesin Berkas Elektron (MBE), dan alat pencacahan Spektrometer Gamma Tipe Quartz 12512/3 A-Dz 393 menggunakan detektor $\mathrm{NaI}(\mathrm{TI})$ pada kondisi kerja, Tegangan 600 V Canberra 3002, pre Amp 100V Ortec 311, penganalisis Salur Ganda (Multi Channel analyzer / MCA) 7010.

\section{Proses Pembuatan Batik}

Masing-masing bahan ZWA diekstraksi menjadi ZWA siap pakai. Proses ekstraksi merupakan proses pembuatan larutan ZWA untuk pengambilan pigmen pembangkit warna yang terdapat pada bahan. Ekstraksi dilakukan dengan cara merebus bahan ZWA dengan menggunakan air. dengan perbandingan sebesar 1:7, yang artinya $1 \mathrm{~kg}$ untuk masing tanaman ZWA dengan 7 liter air.

Kain katun dengan ukuran $50 \mathrm{~cm}$ dimordan menggunakan larutan tawas $40 \mathrm{~g} / \mathrm{l}$ kemudian dikeringkan tanpa diperas. Proses tersebut berfungsi untuk memperlebar serat kain dan membersihkan kotoran. Kain katun kemudian dibatik dengan proses cap dan dicelup dalam larutan ekstrak ZWA masing-masing dua kali celupan dan dikeringkan. Proses fiksasi dilakukan dengan memasukkan kain ke dalam larutan kapur, tawas dan tunjung. Kain dicuci hingga bersih kemudian dilakukan pelepasan malam (nglorod). Kain dicuci kembali dan dikeringkan, sehingga diperoleh kain batik warna alam.

\section{Proses Iradiasi Berkas Elektron}

Proses iradiasi dilakukan menggunakan MBE milik Pusat Sains dan Teknologi Akselerator (PSTA)-BATAN Yogyakarta yang dirancang untuk tenaga sebesar $350 \mathrm{keV} / 10$ mA. Namun, pada saat percobaan hanya 
dioperasikan pada kondisi kerja dengan tegangan sebesar 300 kV (300 keV). Kain batik yang sudah siap selanjutnya diiradiasi menggunakan MBE dengan waktu iradiasi 15 dan 30 detik sehingga didapatkan dosis yang diinginkan. Nilai dosis didapatkan dari pembacaan CTA hasil iradiasi menggunakan alat CTA dosimeter sehingga didapatkan nilai dosis sebesar 34,08 kGy untuk waktu 15 detik dan 62,32 kGy untuk waktu 30 detik. Adapun proses radiasi dilakukan pada kain batik dengan pewarna masing-masing ZWA tanpa fiksasi dan menggunakan masing-masing ZWA dengan variasi 3 (tiga) tiga jenis fiksator. Keterangan kode sampel disajikan pada Tabel 1 sampai Tabel 4.

\section{Pengujian}

Kain batik yang telah diiradiasi kemudian diuji ketahanan lunturnya di Laboratorium Pengujian, Balai Besar Kerajinan dan Batik (BBKB) Yogyakarta. Pengujian ketahanan luntur warna batik disesuaikan dengan ketentuan pada SNI Batik. Jenis uji ketahanan luntur yang dilakukan ditunjukkan pada Tabel 5.

Tabel 1. Kode sampel untuk kain batik dengan pewarnaan secang (Caesalpinia sappan)

\begin{tabular}{ccl}
\hline No & $\begin{array}{c}\text { Kode } \\
\text { sampel }\end{array}$ & Proses Perlakuan Sampel \\
\hline $\mathbf{1}$ & A1.1 & kain batik dengan ZWA secang tanpa fiksasi yang diradiasi selama 15 menit \\
$\mathbf{2}$ & A1.2 & kain batik dengan ZWA secang tanpa fiksasi yang diradiasi selama 30 menit \\
$\mathbf{3}$ & A2.1 & kain batik dengan ZWA secang dengan fiksasi tawas diradiasi selama 15 menit \\
$\mathbf{4}$ & A2.2 & kain batik dengan ZWA secang dengan fiksasi tawas diradiasi selama 30 menit \\
$\mathbf{5}$ & A3.1 & kain batik dengan ZWA secang dengan fiksasi tunjung diradiasi selama 15 menit \\
$\mathbf{6}$ & A3.2 & kain batik dengan ZWA secang dengan fiksasi tunjung diradiasi selama 30 menit \\
$\mathbf{7}$ & A4.1 & kain batik dengan ZWA secang dengan fiksasi kapur diradiasi selama 15 menit \\
$\mathbf{8}$ & A4.2 & kain batik dengan ZWA secang dengan fiksasi kapur diradiasi selama 30 menit \\
\hline
\end{tabular}

Tabel 2. Kode sampel untuk kain batik dengan pewarnaan mahoni (Swietenia mahagoni).

\begin{tabular}{ccl}
\hline No & $\begin{array}{c}\text { Kode } \\
\text { Sampel }\end{array}$ & Proses Perlakuan sampel \\
\hline $\mathbf{1}$ & B1.1 & kain batik dengan ZWA mahoni tanpa fiksasi yang diradiasi selama 15 menit \\
$\mathbf{2}$ & B1.2 & kain batik dengan ZWA mahoni tanpa fiksasi yang diradiasi selama 30 menit \\
$\mathbf{3}$ & B2.1 & kain batik dengan ZWA mahoni dengan fiksasi tawas diradiasi selama 15 menit \\
$\mathbf{4}$ & B2.2 & kain batik dengan ZWA mahoni dengan fiksasi tawas diradiasi selama 30 menit \\
$\mathbf{5}$ & B3.1 & kain batik dengan ZWA mahoni dengan fiksasi tunjung diradiasi selama 15 menit \\
$\mathbf{6}$ & B3.2 & kain batik dengan ZWA mahoni dengan fiksasi tunjung diradiasi selama 30 menit \\
$\mathbf{7}$ & B4.1 & kain batik dengan ZWA mahoni dengan fiksasi kapur diradiasi selama 15 menit \\
$\mathbf{8}$ & B4.2 & kain batik dengan ZWA mahoni dengan fiksasi kapur diradiasi selama 30 menit \\
\hline
\end{tabular}

Tabel 3. Kode sampel untuk kain batik dengan pewarnaan Tegeran (Cudrania javanensis)

\begin{tabular}{ccl}
\hline No & $\begin{array}{c}\text { Kode } \\
\text { Sampel }\end{array}$ & \multicolumn{1}{c}{ Proses Perlakuan sampel } \\
\hline $\mathbf{1}$ & $\mathrm{C} 1.1$ & kain batik dengan ZWA tegeran tanpa fiksasi diradiasi selama 15 menit \\
$\mathbf{2}$ & $\mathrm{C} 1.2$ & kain batik dengan ZWA tegeran tanpa fiksasi diradiasi selama 30 menit \\
$\mathbf{3}$ & $\mathrm{C} 2.1$ & kain batik dengan ZWA tegeran dengan fiksasi tawas diradiasi selama 15 menit \\
$\mathbf{4}$ & $\mathrm{C} 2.2$ & $\begin{array}{l}\text { kain batik dengan ZWA tegeran dengan fiksasi tawas diradiasi selama } 30 \text { menit } \\
\mathbf{5}\end{array}$ \\
$\mathrm{C} 3.1$ & $\begin{array}{l}\text { kain batik dengan ZWA tegeran dengan fiksasi tunjung diradiasi selama 15 } \\
\text { menit }\end{array}$ \\
\hline
\end{tabular}


ClKh Dinamika Kerajinan dan Batik: Majalah Ilmiah. Vol. 37 No. 1, Juni 2020, hal. 105 - 118

\begin{tabular}{ccl}
\hline $\mathbf{6}$ & C3.2 & $\begin{array}{l}\text { kain batik dengan ZWA tegeran dengan fiksasi tunjung diradiasi selama } 30 \\
\text { menit }\end{array}$ \\
$\mathbf{7}$ & C4.1 & $\begin{array}{l}\text { kain batik dengan ZWA tegeran dengan fiksasi kapur diradiasi selama } 15 \text { menit } \\
\mathbf{8}\end{array}$ \\
C4.2 & kain batik dengan ZWA tegeran dengan fiksasi kapur diradiasi selama 30 menit \\
\hline
\end{tabular}

Tabel 4. Kode sampel untuk kain batik dengan pewarnaan Tingi (Ceriops taga)

\begin{tabular}{ccl}
\hline No & $\begin{array}{c}\text { Kode } \\
\text { Sampel }\end{array}$ & Proses Perlakuan sampel \\
\hline $\mathbf{1}$ & D1.1 & kain batik dengan ZWA tingi tanpa fiksasi diradiasi selama 15 menit \\
$\mathbf{2}$ & D1.2 & kain batik dengan ZWA tingi tanpa fiksasi diradiasi selama 30 menit \\
$\mathbf{3}$ & D2.1 & kain batik dengan ZWA tingi dengan fiksasi tawas diradiasi selama 15 menit \\
$\mathbf{4}$ & D2.2 & kain batik dengan ZWA tingi dengan fiksasi tawas diradiasi selama 30 menit \\
$\mathbf{5}$ & D3.1 & kain batik dengan ZWA tingi dengan fiksasi tunjung diradiasi selama 15 menit \\
$\mathbf{6}$ & D3.2 & kain batik dengan ZWA tingi dengan fiksasi tunjung diradiasi selama 30 menit \\
$\mathbf{7}$ & D4.1 & kain batik dengan ZWA tingi dengan fiksasi kapur diradiasi selama 15 menit \\
$\mathbf{8}$ & D4.2 & kain batik dengan ZWA tingi dengan fiksasi kapur diradiasi selama 30 menit \\
\hline
\end{tabular}

Tabel 5. Metode uji kualitas batik berdasarkan parameter uji ketahanan luntur

\begin{tabular}{ccc}
\hline No & \multicolumn{1}{c}{ Parameter Uji } & Metode Uji \\
\hline 1 & Ketahanan luntur warna terhadap pencucian $40^{\circ} \mathrm{C}$ & SNI ISO 105-C06:2010 \\
& a) Nilai perubahan warna & SNI ISO 105-A02:2010 \\
b) Nilai Penodaan warna & SNI ISO 105-A03:2010 \\
2 & $\begin{array}{l}\text { Ketahanan luntur warna terhadap sinar: } \\
\text { Terang hari yaitu nilai tahan sinar }\end{array}$ & SNI ISO 105-B01:2010 \\
3 & $\begin{array}{l}\text { Ketahanan warna terhadap gosokan: } \\
\text { Nilai penodaan warna }\end{array}$ & SNI ISO 105-A02:2010 \\
& 1) Kapas kering & \\
2) Kapas basah & SNI ISO 105-X12:2012 \\
& & SNI ISO 105-A03:2010 \\
\hline
\end{tabular}

\section{HASIL DAN PEMBAHASAN}

Salah satu kualitas kain batik yang diharapkan oleh konsumen adalah memiliki ketahanan luntur yang baik (Andriani, Setiaji, \& Habriantama, 2019). Pada pembuatan batik dengan proses pewarnaan alam, peningkatan ketahanan luntur warna dilakukan melalui proses fiksasi sebagai proses pengikatan ZWA ke dalam serat kain (pengunci warna). Pada penelitian ini proses tersebut dilakukan menggunakan aplikasi MBE. Aplikasi MBE untuk pelapisan permukaan kain (curing) merupakan satu di antara sekian banyak aplikasi teknologi MBE.

Pada proses radiasi, berkas elektron berlaku sebagai sumber energi yang berfungsi untuk mempermudah atau mempercepat reaksi kimia yang diperlukan dalam proses pelapisan permukaan. Pada cara konvensional, reaksi kimia biasanya berlangsung melalui inisiator bahan kimia dan energi panas. Tetapi dengan radiasi berkas elektron pemakaian bahan kimia dan panas menjadi berkurang, baik jenis maupun kadamya, karena sudah terwakili oleh sumber radiasi elektron tersebut. Oleh karena itu prosesnya dapat dilakukan pada temperatur kamar. Di samping itu prosesnya mudah dikontrol atau dipantau, sederhana, cepat, dan bebas pencemaran lingkungan (Pudjorahardjo, 2006). Kain batik 
kain batik warna alam yang telah diiradiasi diuji ketahanan lunturnya.

Parameter uji ketahanan luntur batik terdiri dari 3 parameter uji yaitu ketahanan luntur terhadap pencucian, sinar terang hari dan gosokan. Hasil pengujian ketahanan luntur dinyatakan dalam rentang skala dari angka 1 (kurang baik) sampai angka 5 (sangat baik).

Tabel 6. Data uji kelunturan batik dengan pewarnaan Secang (Caesalpinia sappan) menggunakan energi radiasi berkas elektron

\begin{tabular}{|c|c|c|c|c|c|c|c|c|c|}
\hline \multirow[t]{2}{*}{ No } & \multirow[t]{2}{*}{ Parameter Uji } & \multicolumn{8}{|c|}{ Hasil Uji Berdasarkan Kode Sampel } \\
\hline & & $\begin{array}{c}\text { A1. } \\
1\end{array}$ & $\begin{array}{c}\text { A1. } \\
2\end{array}$ & $\begin{array}{c}\text { A2. } \\
1\end{array}$ & A2.2 & $\begin{array}{c}\text { A3. } \\
1\end{array}$ & $\begin{array}{c}\text { A3. } \\
2\end{array}$ & $\begin{array}{c}\text { A4. } \\
1\end{array}$ & A4.2 \\
\hline \multirow[t]{3}{*}{1} & $\begin{array}{l}\text { Ketahanan luntur warna } \\
\text { terhadap pencucian } 40^{\circ} \mathrm{C}\end{array}$ & & & & & & & & \\
\hline & a) Nilai perubahan warna & 2 & 3 & 4 & 4 & 4 & 4 & 4 & 4 \\
\hline & b) Nilai Penodaan warna & 3 & 4 & $4-5$ & 4 & $4-5$ & $4-5$ & $4-5$ & $4-5$ \\
\hline 2 & $\begin{array}{l}\text { Ketahanan luntur warna } \\
\text { terhadap sinar: terang hari } \\
\text { yaitu nilai tahan sinar }\end{array}$ & 3 & 4 & $4-5$ & 4 & $4-5$ & 4 & $4-5$ & 4 \\
\hline \multirow[t]{3}{*}{3} & $\begin{array}{l}\text { Ketahanan warna terhadap } \\
\text { gosokan: } \\
\text { Nilai penodaan warna }\end{array}$ & & & & & & & & \\
\hline & a) Kapas kering & 2 & 4 & $4-5$ & 4 & $4-5$ & $4-5$ & $4-5$ & 4 \\
\hline & b) Kapas basah & $2-3$ & 4 & 4 & $3-4$ & 3 & 3 & 4 & $3-4$ \\
\hline
\end{tabular}

Keterangan: 1=Kurang Baik 2=Agak Baik 3 =Cukup baik $4=$ =Baik 5 =Sangat Baik

Tabel 7. Data uji kelunturan batik dengan pewarnaan Mahoni (Swietenia mahagoni) menggunakan energi radiasi berkas elektron

\begin{tabular}{|c|c|c|c|c|c|c|c|c|c|}
\hline \multirow[t]{2}{*}{ No } & \multirow[t]{2}{*}{ Parameter Uji } & \multicolumn{8}{|c|}{ Hasil Uji Berdasarkan Kode Sampel } \\
\hline & & $\begin{array}{c}\text { B1. } \\
1\end{array}$ & B1.2 & $\begin{array}{c}\text { B2. } \\
1\end{array}$ & B2.2 & $\begin{array}{c}\text { B3. } \\
1\end{array}$ & $\begin{array}{c}\text { B3. } \\
2\end{array}$ & $\begin{array}{c}\text { B4. } \\
1\end{array}$ & B4.2 \\
\hline \multirow[t]{3}{*}{1} & $\begin{array}{l}\text { Ketahanan luntur warna } \\
\text { terhadap pencucian } 40^{\circ} \mathrm{C}\end{array}$ & & & & & & & & \\
\hline & a) Nilai perubahan warna & 3 & 4 & 4 & 4 & 4 & 4 & 4 & 4 \\
\hline & b) Nilai Penodaan warna & 4 & $4-5$ & $4-5$ & $4-5$ & $4-5$ & $4-5$ & $4-5$ & $4-5$ \\
\hline \multirow[t]{2}{*}{2} & Ketahanan luntur warna & & & & & & & & \\
\hline & $\begin{array}{l}\text { terhadap sinar: terang hari } \\
\text { yaitu nilai tahan sinar }\end{array}$ & $3-4$ & 4 & $4-5$ & 4 & $4-5$ & $4-5$ & 4 & $4-5$ \\
\hline \multirow[t]{3}{*}{3} & $\begin{array}{l}\text { Ketahanan warna terhadap } \\
\text { gosokan: } \\
\text { Nilai penodaan warna }\end{array}$ & & & & & & & & \\
\hline & a) Kapas kering & 4 & 4 & 4 & $4-5$ & 4 & $4-5$ & 4 & 4 \\
\hline & b) Kapas basah & $3-4$ & $3-4$ & 2 & $4-5$ & $3-4$ & 4 & $3-4$ & $3-4$ \\
\hline
\end{tabular}

Keterangan: 1=Kurang Baik $2=$ =Agak Baik $3=$ =ukup baik $4=$ Baik $5=$ Sangat Baik 
IIKh Dinamika Kerajinan dan Batik: Majalah Ilmiah. Vol. 37 No. 1, Juni 2020, hal. 105 - 118

Tabel 8. Data uji kelunturan batik dengan ZWA Tegeran (Cudrania javanensis) menggunakan energi radiasi berkas elektron

\begin{tabular}{|c|c|c|c|c|c|c|c|c|c|}
\hline \multirow[t]{2}{*}{ No } & \multirow[t]{2}{*}{ Parameter Uji } & \multicolumn{8}{|c|}{ Hasil Uji Berdasarkan Kode Sampel } \\
\hline & & $\begin{array}{c}\text { C1. } \\
1\end{array}$ & C1.2 & $\begin{array}{c}\mathrm{C} 2 . \\
1\end{array}$ & C2.2 & $\begin{array}{c}\text { C3. } \\
1\end{array}$ & $\begin{array}{c}\text { C3. } \\
2\end{array}$ & $\begin{array}{c}\text { C4. } \\
1\end{array}$ & C4.2 \\
\hline \multirow[t]{3}{*}{1} & $\begin{array}{l}\text { Ketahanan luntur warna } \\
\text { terhadap pencucian } 40^{\circ} \mathrm{C}\end{array}$ & & & & & & & & \\
\hline & a) Nilai perubahan warna & 3 & 4 & 4 & 4 & 4 & 4 & 4 & 4 \\
\hline & b) Nilai penodaan warna & 4 & $4-5$ & $4-5$ & $4-5$ & $4-5$ & $4-5$ & $4-5$ & $4-5$ \\
\hline 2 & $\begin{array}{l}\text { Ketahanan luntur warna } \\
\text { terhadap sinar: terang hari } \\
\text { yaitu nilai tahan sinar }\end{array}$ & $3-4$ & $3-4$ & $4-5$ & 4 & $4-5$ & $4-5$ & 4 & 4 \\
\hline \multirow[t]{3}{*}{3} & $\begin{array}{l}\text { Ketahanan warna terhadap } \\
\text { gosokan: } \\
\text { Nilai penodaan warna }\end{array}$ & & & & & & & & \\
\hline & a) Kapas kering & 4 & 4 & 4 & $4-5$ & 4 & $4-5$ & 4 & 4 \\
\hline & b) Kapas basah & $3-4$ & $3-4$ & 2 & $4-5$ & $3-4$ & 4 & $3-4$ & $3-4$ \\
\hline
\end{tabular}

Keterangan: 1=Kurang Baik 2=Agak Baik 3 =Cukup baik 4=Baik $5=$ Sangat Baik

Tabel 9. Data uji kelunturan batik dengan ZWA Tingi (Ceriops tagal) menggunakan energi radiasi berkas elektron

\begin{tabular}{|c|c|c|c|c|c|c|c|c|c|}
\hline \multirow[t]{2}{*}{ No } & \multirow[t]{2}{*}{ Parameter Uji } & \multicolumn{8}{|c|}{ Hasil Uji Berdasarkan Kode Sampel } \\
\hline & & D1.1 & D1.2 & D2.1 & D2.2 & D3.1 & D3.2 & D4.1 & D4.2 \\
\hline \multirow[t]{3}{*}{1} & $\begin{array}{l}\text { Ketahanan luntur warna } \\
\text { terhadap pencucian } 40^{\circ} \mathrm{C}\end{array}$ & & & & & & & & \\
\hline & a) Nilai perubahan warna & 3 & 4 & 4 & 4 & 4 & 4 & 4 & 4 \\
\hline & b) Nilai Penodaan warna & 4 & $4-5$ & $4-5$ & $4-5$ & $4-5$ & $4-5$ & $4-5$ & $4-5$ \\
\hline 2 & $\begin{array}{l}\text { Ketahanan luntur warna } \\
\text { terhadap sinar: terang hari } \\
\text { yaitu nilai tahan sinar }\end{array}$ & $3-4$ & $3-4$ & $3-4$ & 4 & $4-5$ & $4-5$ & $3-4$ & $4-5$ \\
\hline \multirow[t]{3}{*}{3} & $\begin{array}{l}\text { Ketahanan warna terhadap } \\
\text { gosokan: } \\
\text { Nilai penodaan warna }\end{array}$ & & & & & & & & \\
\hline & a) Kapas kering & 4 & 4 & $4-5$ & $4-5$ & 4 & $4-5$ & 4 & $4-5$ \\
\hline & b) Kapas basah & $3-4$ & $3-4$ & 4 & $4-5$ & $3-4$ & $4-5$ & $3-4$ & 4 \\
\hline
\end{tabular}

Keterangan: 1=Kurang Baik 2=Agak Baik 3=Cukup baik 4=Baik 5=Sangat Baik

Hasil pengujian kualitas ketahanan luntur warna kain batik dengan pewarnaan secang (Caesalpinia sappan) menggunakan energi radiasi berkas elektron disajikan dalam Tabel 6. Untuk kain batik tanpa proses fiksasi (sampel A1.1 dan A1.2) memiliki nilai rata-rata angka 2 (agak baik) dan 2-3 (agak baik sampai baik) untuk parameter uji ketahanan luntur warna terhadap pencucian $40{ }^{\circ} \mathrm{C}$ dan ketahanan luntur warna terhadap sinar terang hari. Sedangkan untuk kain batik dengan proses fiksasi menggunakan tiga jenis fiksator (sampel A2.1 sampai A4.2) memiliki ratarata nilai yang lebih tinggi yaitu 4 (baik) dan 4-5 (baik sampai sangat baik) untuk parameter uji yang sama. Hal ini menunjukkan bahwa kualitas kain batik dengan proses fiksasi memiliki kualitas ketahanan luntur yang lebih baik 
ClKh Dinamika Kerajinan dan Batik: Majalah Ilmiah. Vol. 37 No. 1, Juni 2020, hal. $105-118$

dibandingkan proses tanpa fiksasi. Pengaruh radiasi berkas elektron pada kain batik baik tanpa proses fiksasi memperlihatkan bahwa waktu iradiasi berkas elektron yang lebih tinggi yaitu 30 detik (setara dosis 62,32 kGy) menghasilkan kualitas ketahanan luntur warna yang lebih baik dibandingkan dengan waktu iradiasi 15 detik (setara dosis 34,08 kGy). Sedangkan pada batik yang difiksasi pengaruhnya tidak begitu signifikan.

Pengujian ketahanan luntur terhadap gosokan terdiri dari dua kategori yaitu gosokan basah (dengan contoh kapas basah) dan gosokan kering (dengan contoh kapas kering). Nilai penodaan warna pada kapas basah merupakan nilai yang secara umum memiliki nilai paling rendah untuk seluruh perlakuan yaitu nilai 2-3 (agak baik sampai cukup) untuk proses tanpa fiksasi, 3 (cukup baik) untuk fiksator tunjung dan maksimal ditunjukkan dengan nilai 4 (baik) untuk fiksator kapur. Hal ini menjelaskan bahwa kain batik dengan ZWA secang (Caesalpinia sappan) baik dengan proses fiksasi maupun tanpa proses fiksasi dilanjutkan dengan proses curing dengan menggunakan energi radiasi berkas elektron tidak mempengaruhi peningkatan kualitas kain batik

Pakaian yang bergesekan dalam keadaan basah atau lembab dapat meninggalkan noda. Pada pengujian ketahanan luntur terhadap gosokan basah, dapat dilihat seberapa banyak noda yang ditinggalkan ketika kain berwarna bergesekan dengan kain kapas dalam keadaan basah. Nilai penodaan warna terhadap kain kapas pada ketahanan luntur gosokan basah yang rendah menunjukkan bahwa pada saat pengujian banyak noda yang tertinggal pada kain.

Kualitas kain batik dengan pewarnaan menggunakan mahoni (Swietenia mahagoni) disajikan pada Tabel 7. Tabel 7 menunjukkan bahwa kain batik tanpa proses fiksasi dengan waktu iradiasi berkas elektron selama 15 detik (sampel B1.1) memiliki rata-rata nilai paling rendah dari semua keseluruhan sampel (sampel B1.2 sampai B4.2). Sedangkan kain batik dengan proses tanpa fiksasi dengan waktu iradiasi berkas elektron selama 30 detik (sampel B1.2) memiliki rata-rata nilai hampir sama yaitu 4 dan 4-5 dengan kategori baik untuk keseluruhan parameter uji pada kain batik dengan proses fiksasi dengan ketiga jenis fiksator. Hal ini menjelaskan bahwa waktu iradiasi selama 30 detik merupakan dosis yang lebih baik dibanding dosis 15 detik untuk menghasilkan kualitas batik yang baik dan dapat dipertimbangkan sebagai salah satu upaya substitusi fiksator Dalam proses pewarnaan alam menggunakan mahoni (Swietenia mahagoni). Dari keseluruhan nilai parameter uji untuk kain batik dengan proses fiksator baik menggunakan tawas, tunjung dan kapur dengan radiasi berkas elektron dengan waktu iradiasi 30 detik memiliki nilai kualitas ketahanan luntur warna yang lebih tinggi dibandingkan waktu iradiasi 15 detik. Hal ini menjelaskan bahwa semakin tinggi waktu iradiasi berkas elektron maka semakin banyak warna ZWA Mahoni (Swietenia mahagoni) yang terikat ke dalam serat kain katun. Nilai ketahanan luntur warna untuk gosokan basah pada kain batik dengan pewarnaan mahoni ratarata memiliki nilai 3 (cukup baik) untuk proses tanpa fiksasi maupun dengan proses fiksasi namun hanya satu nilai 2 (kurang 
baik) pada sampel B2.1 yaitu kain batik dengan fiksator tawas pada waktu iradiasi berkas elektron 15 detik.

Tabel 8 menunjukkan data uji ketahanan luntur warna batik dengan pewarna alami Tegeran (Cudrania javanensis) menggunakan waktu iradiasi berkas elektron sebesar 15 detik dan 30 detik. Nilai yang ditunjukkan seluruh parameter uji ketahanan luntur pada kain batik dengan pewarnaan mahoni (Swietenia mahagoni) hampir sama dengan kain batik dengan pewarnaan tegeran (Cudrania javanensis). Tabel 8 memperlihatkan bahwa kain batik dengan proses tanpa fiksasi dengan waktu iradiasi berkas elektron selama 15 detik (sampel C1.1) memiliki rata-rata nilai paling rendah dari semua keseluruhan sampel (sampel C1.2 sampai C4.2), sedangkan kain batik dengan proses tanpa fiksasi pada waktu iradiasi berkas elektron 30 detik (sampel C1.2) memiliki rata-rata nilai hampir sama untuk keseluruhan parameter uji pada kain batik dengan proses fiksasi dengan ketiga jenis fiksator. Hal ini menjelaskan bahwa iradiasi dengan waktu 30 detik merupakan dosis optimum yang dapat dipertimbangkan sebagai alternatif fiksator untuk pewarnaan tegeran (Cudrania javanensis). Dari keseluruhan nilai parameter uji untuk kain batik yang difiksasi menggunakan tawas, tunjung dan kapur dengan radiasi berkas elektron dengan waktu iradiasi selama 30 detik memiliki nilai kualitas ketahanan luntur warna yang lebih tinggi dibandingkan waktu iradiasi selama 15 detik. Hal ini menjelaskan bahwa semakin tinggi waktu iradiasi berkas elektron maka dapat mengikat warna ZWA tegeran (Cudrania javanensis) lebih banyak dalam serat kain katun. Nilai ketahanan luntur warna untuk gosokan basah pada kain batik ZWA mahoni rata-rata memiliki nilai 3 (cukup baik) untuk proses tanpa fiksasi maupun dengan proses fiksasi namun hanya satu nilai 2 (kurang baik) pada kode sampel B2.1 yaitu kain batik dengan fiksator tawas pada waktu iradiasi berkas elektron 15 detik. Tabel 8 menjelaskan juga tentang nilai ketahanan luntur warna terhadap gosokan, pada penodaan kapas basah dan uji ketahanan luntur terhadap sinar matahari yang mempunyai nilai ratarata paling rendah.

Hasil pengujian kain batik dengan pewarnaan tingi (Ceriops taga) disajikan pada Tabel 9. Tabel 9 memperlihatkan bahwa kain batik dengan pewarnaan tingi (Ceriops tagal) memiliki keseluruhan nilai parameter ketahanan luntur warna tanpa proses fiksasi dengan waktu iradiasi berkas elektron 15 detik (sampel D1.1) memiliki nilai yang secara rata-rata lebih rendah dibandingkan dengan waktu iradiasi berkas elektron 30 detik (sampel D1.2). Hal ini menandakan bahwa kain batik dengan pewarnaan tingi (Ceriops tagal) dengan proses fiksasi menggunakan variasi ketiga fiksator pada waktu iradiasi berkas elektron 30 detik lebih optimum untuk menghasilkan kualitas batik yang lebih baik dibandingkan waktu iradiasi 15 detik, namun nilai yang dihasilkan rata-rata sama baik untuk proses tanpa fiksasi maupun dengan fiksasi yaitu nilai 4 (baik) atau 4-5 (baik sampai sangat baik). Hal ini artinya proses curing dengan aplikasi radiasi berkas elektron tidak mempengaruhi kualitas ketahanan luntur warna kain batik dengan pewarnaan menggunakan tingi (Ceriops tagal) baik untuk proses tanpa fiksasi maupun dengan proses fiksasi. Tabel 9 menjelaskan juga 
tentang nilai ketahanan luntur warna terhadap gosokan, pada penodaan kapas basah dan uji ketahanan luntur terhadap sinar matahari yang mempunyai nilai ratarata paling rendah. Pada umumnya pewarnaan memiliki nilai rendah untuk uji ketahanan luntur terhadap sinar matahari. Hal ini disebabkan ZWA berasal dari bahan organik dimana rantai ikatan kimia sangat mudah terputus apabila terkena sinar matahari.

Pembahasan di atas menunjukkan bahwa radiasi berkas elektron dapat mempengaruhi kualitas hasil proses pewarnaan batik dari segi ketahanan luntur warna. Pemanfaatan teknologi radiasi dalam pembatikan zat warna alam dapat mengurangi kuantitas limbah cair industri batik karena proses radiasi tidak melibatkan air dalam prosesnya. Teknologi radiasi ini juga merupakan salah satu upaya pengganti fiksator logam berat sehingga limbah batik yang dihasilkan akan lebih aman terhadap lingkungan. Oleh karena itu batik dengan teknologi radiasi dapat dikatakan batik ramah lingkungan dengan kualitas yang baik sesuai standar SNI Batik untuk mewujudkan industri batik yang berkelanjutan.

\section{KESIMPULAN DAN SARAN}

Kesimpulan

Dari hasil penelitian ini dapat disimpulkan bahwa radiasi berkas elektron yang dihasilkan MBE dapat diaplikasikan untuk melapisi permukaan kain melalui proses curing sehingga dapat meningkatkan kualitas nilai ketahanan luntur warna kain batik dengan ZWA. Radiasi berkas elektron berpotensi sebagai pengganti proses fiksasi kain batik dengan pewarnaan secang (Caesalpinia sappan), mahoni (Swietenia mahagoni) dan tegeran (Cudrania javanensis), akan tetapi kurang berpengaruh pada kain batik dengan pewarnaan tingi (Ceriops tagal). Semakin besar waktu iradiasi berkas elektron maka akan mempengaruhi kenaikan nilai uji ketahanan luntur warna kain batik dengan pewarnaan alam untuk parameter uji ketahanan luntur terhadap pencucian dan sinar terang hari.

Radiasi berkas elektron tidak mempengaruhi kualitas ketahanan luntur warna terhadap gosokan khususnya kapas basah pada kain batik dengan keempat jenis ZWA yaitu secang (Caesalpinia sappan), tegeran (Cudrania javanensis), mahoni (Swietenia mahagoni), dan tingi (Ceriops tagah).

\section{Saran}

Perlu dilakukan penelitian lanjutan dengan variasi besaran waktu iradiasi berkas elektron yang lebih beragam untuk mendapatkan dosis yang paling optimum untuk menghasilkan kualitas kain batik yang paling baik.

\section{KONTRIBUSI PENULIS}

Semua penulis merupakan kontributor utama.

\section{UCAPAN TERIMA KASIH}

Terima kasih kepada program pembinaan Pusat Unggulan IPTEK (PUI) Kementerian Riset dan Teknologi/Badan Riset dan Inovasi Negara yang mendanai penelitian ini.

\section{DAFTAR PUSTAKA}

Adeel, S., Bhatti, I. A., Kausar, A., \& Osman, E. (2012). Influence of UV radiations on the extraction and dyeing of cotton fabric with 
ClKh Dinamika Kerajinan dan Batik: Majalah Ilmiah. Vol. 37 No. 1, Juni 2020, hal. 105 - 118

Curcuma longa L. Indian Journal of Fibre and Textile Research, 37(1), 87-90.

Ahmad, I., Adeel, S., \& Abbas, M. (2011). Effect of Radiation on Textile Dyeing. Textile Dyeing, (December). https://doi.org/10.5772/19879

Amalia, R., \& Akhtamimi, I. (2016). Studi Pengaruh Jenis dan Konsentrasi Zat Fiksasi terhadap Kualitas Warna Kain Batik dengan Pewarna Alam Limbah Kulit Buah Rambutan (Nephelium lappaceum). Dinamika Kerajinan Dan Batik, 33(2), 85-92.

Andriani, D. P., Setiaji, U., \& Habriantama, M. (2019). Optimasi Parameter Ketahanan Luntur Batik terhadap Keringat dengan Desain Eksperimen Taguchi. Dinamika Kerajinan Dan Batik: Majalah IImiah, 36(1), 81-94.

https://doi.org/10.22322/dkb.V36i1.4149

Danu, S., \& Darsono, D. (2010). Electron Beam Curing of Epoxy Acrylate Coatings on Medium-Density Fiberboard. Indonesian Journal of Chemistry, 8(2), 207-214. https://doi.org/10.22146/ijc.21624

Darsono, Sukidi, \& Purwanto, A. T. (2010). UJI COBA (KONDISIONING) KOMPONEN MBE $300 \mathrm{keV} / 20 \mathrm{~mA}$ UNTUK INDUSTRI LATEKS TAHAP I, 220-225.

Hakeim, O. A., Abdou, L. A. W., El-Gammal, M. S., \& El-Naggar, A. M. (2012). An approach for vat color printing on cotton and polyester fabrics with electron beam irradiation curable formulations. Carbohydrate Polymers, 87(2), 1467-1475. https://doi.org/https://doi.org/10.1016/j.ca rbpol.2011.09.043

Ho, Y. C. (2018). Special Relationship in the Malay World: Indonesia and Malaysia. Singapore: ISEAS-Yusof Ishak Institute.

Iqbal, J., \& Adeel, S. (2008). Effect of UV radiation on dyeing of cotton fabric with extracts of henna leaves. Indian Journal of Fibre and Textile Research, 33.

Licari, J. J., \& Swanson, D. W. (2011). 1 Introduction. In J. J. Licari \& D. W. B. T.-A. T. for E. A. (Second E. Swanson (Eds.), Materials and Processes for Electronic Applications (pp. 1-34). Oxford: William Andrew Publishing. https://doi.org/https://doi.org/10.1016/B97 8-1-4377-7889-2.10001-4

Mahreni. (2016). Batik Warna Alami. Yogyakarta: UPN "Veteran" Yogyakarta.
Meutia, M. (2013). Improving Competitive Advantage and Business Performance Through the Development of Business Network, Adaptability of Business Environment and Innovation Creativity: an Empirical Study of Batik Small and Medium Enterprises (SME) in Pekalongan, Central Ja. Aceh International Journal of Social Sciences, https://doi.org/10.12345/aijss.2.1.1359

Mitra, A. (2015). Natural dye mordants and their health hazards. Journal of the Textile Association, 75, 405-410.

Mukimin, A., Vistanty, H., Zen, N., Purwanto, A., \& Wicaksono, K. (2018). Performance of bioequalization-electrocatalytic integrated method for pollutants removal of handdrawn batik wastewater. Journal of Water Process Engineering, 21, 77-83. https://doi.org/10.1016/j.jwpe.2017.12.004

Park, S., Son, H., Kwon, I., Sim, J., Lee, J., Kim, M., ... Yeom, J. (2013). KR101485686B1. South Korea.

Patel, B. H. (2011). Natural dyes. Handbook of Textile and Industrial Dyeing: Principles, Processes and Types of Dyes (Vol. 1). Woodhead Publishing Limited. https://doi.org/10.1533/9780857093974.2. 395

Pudjorahardjo, D. S. (2006). Aplikasi Mesin Berkas Elektron Di Pusat Teknologi Akselerator dan Proses Bahan - BATAN. Pertemuan Dan Presentasi Teknologi Akselerator Dan Aplikasinya, Edisi Khus(Juli), 70-77. Retrieved from http://digilib.batan.go.id/e-prosiding/File Prosiding/Lingkungan/Ptapb_2006/data/Dj oko SP 70-77.pdf

Pujilestari, T. (2014). Pengaruh Ekstraksi Zat Warna Alam dan Fiksasi terhadap Ketahanan Luntur Warna pada Kain Batik Katun. Dinamika Kerajinan Dan Batik, 31(1), 31-40.

Samanta, A. K., \& Konar, A. (2011). Dyeing of Textiles with Natural Dyes.pdf. In E. A. Kumbasar (Ed.), Natural Dyes. IntechOpen. https://doi.org/10.5772/1817

Samanta, P. (2020). A Review on Application of Natural Dyes on Textile Fabrics and Its Revival Strategy. https://doi.org/10.5772/intechopen.90038 Shabbir, M. (2019). Textiles and Clothing:

Indrayani, L., dkk, Aplikasi Mesin Berkas Elektron (MBE) sebagai Alternatif Fiksator pada Pewarnaan Batik Warna Alam 
ClKh Dinamika Kerajinan dan Batik: Majalah Ilmiah. Vol. 37 No. 1, Juni 2020, hal. 105 - 118

Environmental Concerns and Solutions.

Beverly: Wiley-Scrivener.

Shahidi, S., Wiener, J., \& Ghoranneviss, M. (2013).

Surface Modification Methods for Improving the Dyeability of Textile Fabrics. In M. Gunay (Ed.), Eco-Friendly Textile Dyeing and Finishing. IntechOpen. https://doi.org/10.5772/53911 
IKh Dinamika Kerajinan dan Batik: Majalah Ilmiah. Vol. 37 No. 1, Juni 2020, hal. 103 - 116 